Archive for

Organic Chemistry

Arkivoc 2017, part v, 196-203

\title{
Synthesis, photo- and ionochromic properties of indolyl(thienyl)maleimides with phenanthroline receptor
}

\section{Evgenii N. Shepelenko, ${ }^{a}$ Oganes G. Karamov, ${ }^{\mathrm{b}}$ Vitaly A. Podshibyakin, ${ }^{\mathrm{b}}$ Yurii V. Revinskii, ${ }^{\mathrm{a}}$}

Karina S. Tikhomirova, ${ }^{b}$ Alexander D. Dubonosov, ${ }^{* a}$ Vladimir A. Bren, ${ }^{b}$ and Vladimir I. Minkin ${ }^{\mathrm{a}, \mathrm{b}}$

a Southern Scientific Center of Russian Academy of Sciences, 41, Chekhov Pr., 344006 Rostov on Don, Russian Federation

${ }^{b}$ Institute of Physical and Organic Chemistry, Southern Federal University, 194/2, Stachka Av., 344090 Rostov on Don, Russian Federation

E-mail: aled@ipoc.sfedu.ru

Received 07-17-2017

Accepted 09-13-2017

Published on line 10-16-2017

\section{Abstract}

Photochromic indolyl(thienyl)maleimides containing phenanthroline receptor in the bridge moiety were synthesized. Ring-opened maleimides possess fluorescence with quantum yields of 0.027-0.037. Irradiation of their solutions with light of $436 \mathrm{~nm}$ results in the formation of non-fluorescent ring-closed isomers. Reopening of the cycle occurs by exposure to visible light $(\lambda>500 \mathrm{~nm})$. The obtained compounds demonstrate selective chemosensor activity to $\mathrm{Fe}^{2+}$ ions.

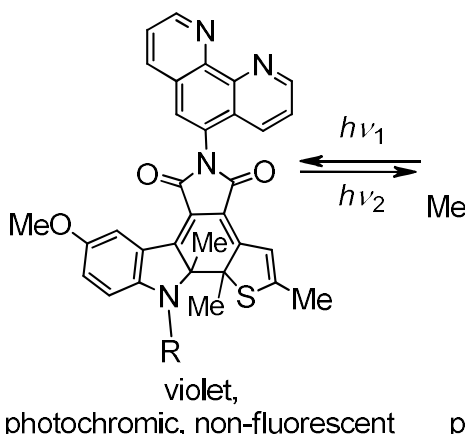

photochromic, non-fluorescent

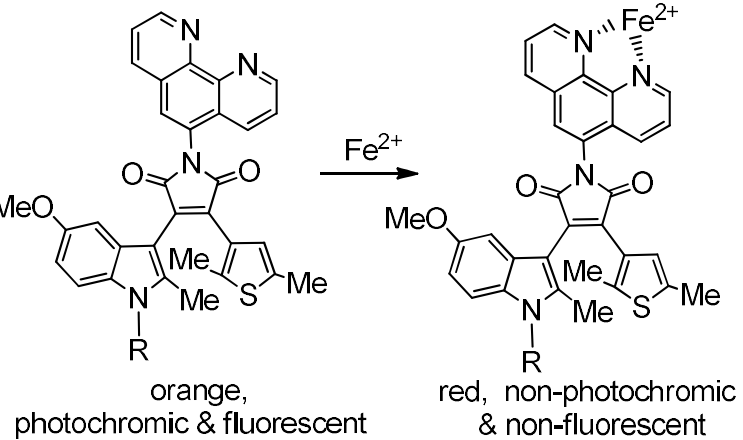

photochromic \& fluorescent

\& non-fluorescent

Keywords: Maleimides, photochromism, ionochromism, fluorescence 


\section{Introduction}

Organic molecular switches represent molecules capable of reversible transformation between two stable states under the influence of external factors: changes in $\mathrm{pH}$, temperature, magnetic field, ionic strength of solution and action of electric current. Photochromic compounds that switch between isomeric states under irradiation with light of a certain wavelength are extensively studied. ${ }^{1-7}$ Spirocyclic compounds, ${ }^{8-10}$ fulgides and fulgimides, ${ }^{11-13}$ dihetarylethenes, ${ }^{14,15}$ photochromic heterocyclic ketoenamines ${ }^{16,17}$ and norbornadienes ${ }^{18,19}$ are of particular interest due to their potential industrial applications, including design of materials for molecular electronics, rewritable optical memory, photo optical commutation, organic displays, photo-pharmacology, biological data visualization, chemo- and biosensors. Chemical modification of photochromic molecules with ionochromic substituents opens new possibilities to create of photo controllable chemosensors in which the coordination and release of ions is modulated with light of different wavelengths. ${ }^{6,20}$ In previous studies, we described the synthesis and investigation of a series of photochromic heterocyclic maleimides, including those capable of detecting cations and anions. ${ }^{16,21,22}$ Herein, we report the synthesis of maleimides containing phenanthroline a receptor group in the bridged pyrrole-2,5-dione moiety and investigation of their photochromic, fluorescent and chemosensor properties. The choice of the phenanthroline as the ligand fragment is due to its significant chemosensor activity towards cations. ${ }^{23-26}$

\section{Results and Discussion}

Furan-2,5-diones 1a-c were synthesized according to previously described procedures (Scheme 1).27,28 Their interaction with 1,10-phenanthroline-5-amine afforded indolyl(thienyl)maleimides 2a-c.

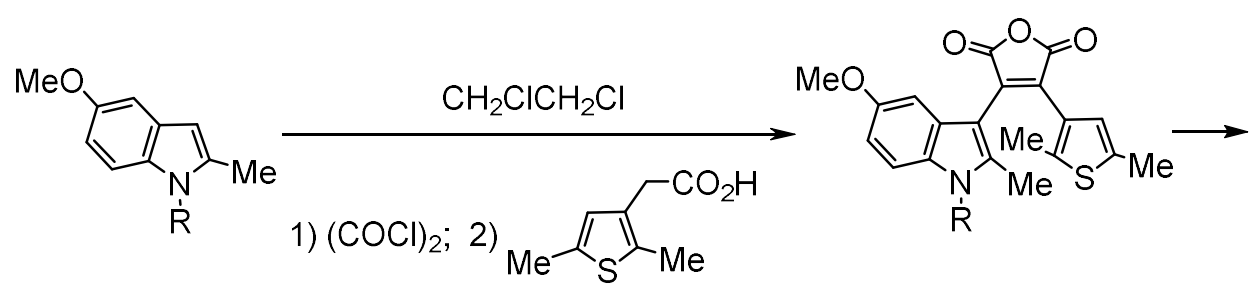

1a-c

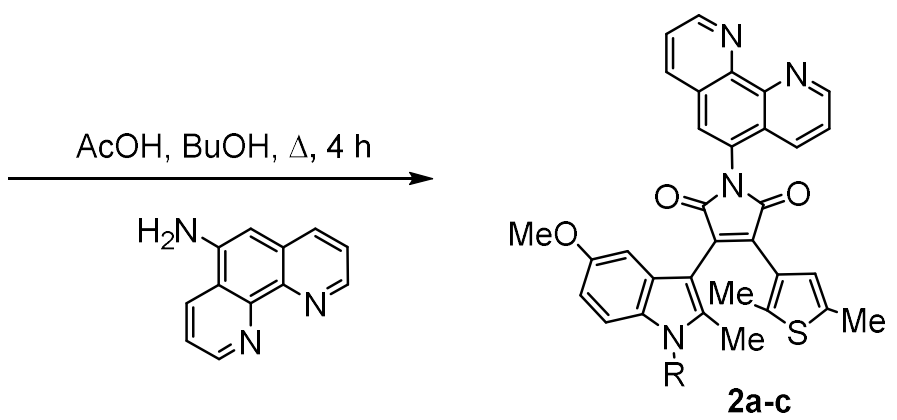

$$
\mathrm{R}=\mathrm{Me}(\mathbf{a}), \mathrm{Et}(\mathbf{b}), \mathrm{CH}_{2} \mathrm{Ph}(\mathbf{c})
$$

Scheme 1. Synthesis of indolyl(thienyl)maleimides 2a-c. 
The structures of synthesized compounds were supported by the data of ${ }^{1} \mathrm{H}$ NMR, IR, mass-spectra and elemental analysis. Spectral-Iuminescent, photochromic and chemosensor properties of maleimides $2 \mathrm{a}-\mathbf{c}$ were studied in toluene and acetonitrile solutions at ambient temperature (Table 1).

Table 1. Spectral absorption and spectral fluorescent characteristics of $\mathbf{2 a - c}$ in toluene

\begin{tabular}{|c|c|c|c|c|c|}
\hline \multirow{3}{*}{ Compound } & \multicolumn{4}{|c|}{ Opened form 0} & \multirow{3}{*}{$\begin{array}{l}\text { Cyclic form C } \\
\text { Absorption, } \\
\lambda_{\text {max., }} \mathrm{nm}\end{array}$} \\
\hline & \multirow{2}{*}{$\begin{array}{c}\text { Absorption, } \\
\lambda_{\max .,} \mathrm{nm} \\
\left(\varepsilon \cdot 10^{-3}\right)\end{array}$} & \multicolumn{3}{|c|}{ Fluorescence } & \\
\hline & & $\begin{array}{l}\text { Excitation } \\
\lambda_{\text {max., }} \mathrm{nm}\end{array}$ & $\begin{array}{l}\text { Emission } \\
\lambda_{\text {max., }} \mathrm{nm}\end{array}$ & $\begin{array}{c}\text { Quantum } \\
\text { yield, } \varphi\end{array}$ & \\
\hline $2 a$ & $470(8.60)$ & 470 & 574 & 0.027 & 599 \\
\hline $2 b$ & $471(7.58)$ & 470 & 575 & 0.024 & 604 \\
\hline $2 c$ & 466 (5.67) & 465 & 571 & 0.037 & 591 \\
\hline
\end{tabular}

Electronic absorption spectra of maleimides $2 \mathrm{a}-\mathrm{c}$ are characterized by long-wave absorption bands with the maxima in the region $466-471 \mathrm{~nm}$ and the molar extinction coefficients of ring-opened $\mathbf{O}$ forms $(5.67-8.60) \cdot 10^{3}$ $\mathrm{L} \mathrm{mol}{ }^{-1} \mathrm{~cm}^{-1}$. Maleimides $2 \mathrm{a}-\mathrm{c}$ exhibit fluorescent properties in solutions: the maxima of the fluorescence bands are in the spectral region at 571-574 $\mathrm{nm}$. The fluorescence excitation spectra are in good agreement with the absorption spectra, which confirms the correctness of attributing the observed emission to the initial ring-opened form $\mathbf{0}$. Irradiation of solutions of compounds $\mathbf{2 a - c}$ in toluene with the filtered light of mercury lamp $436 \mathrm{~nm}$ led to their photocoloration which was attributed to the appearance of new long wavelength absorption bands in the region at 591-604 nm, the intensity of which increased upon irradiation, while the intensity of the initial bands decreased (Fig. 1a). Three distinct isosbestic points were also observed and the intensity of the fluorescence bands decreased without any change of their maxima (Fig. 1b). Prolonged irradiation, however, did not lead to complete quenching of the emission properties.
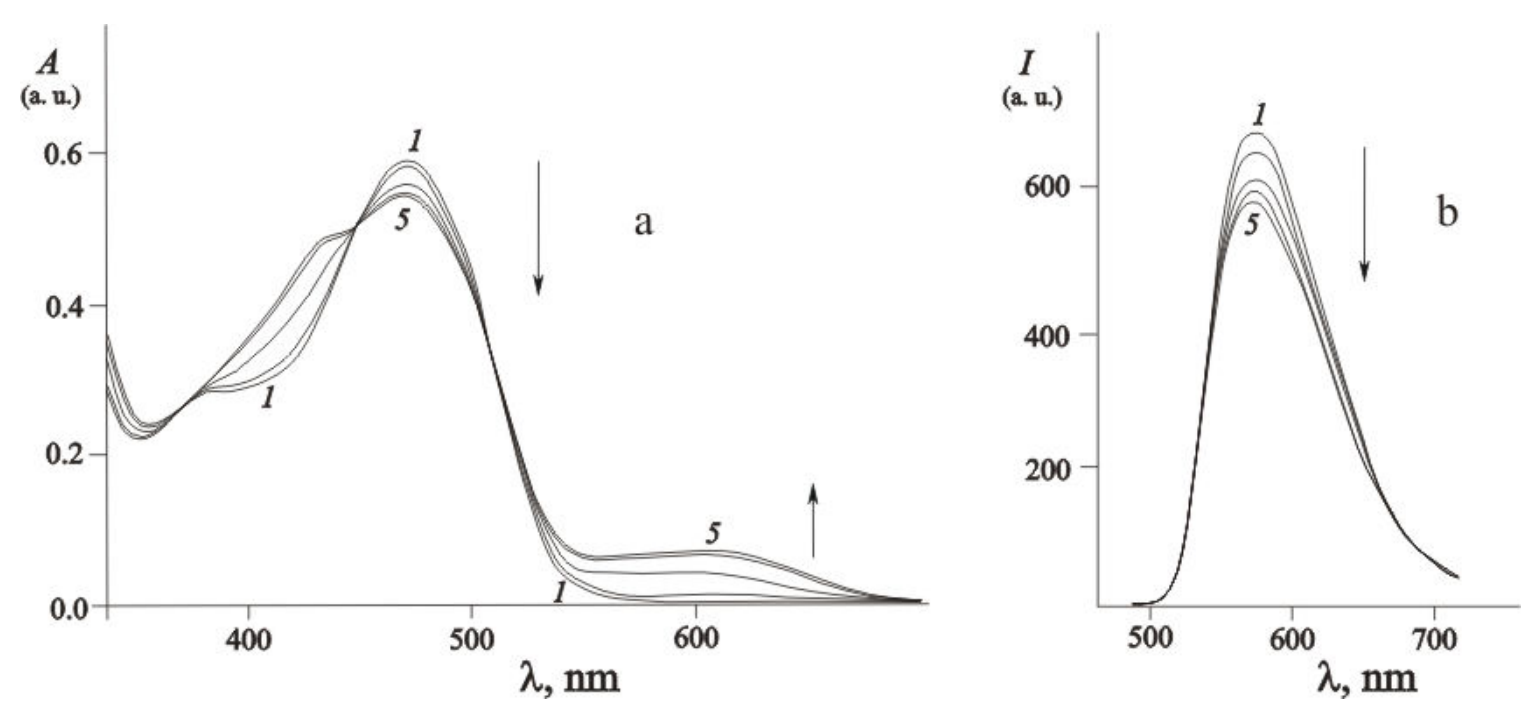

Figure 1. Electronic spectra of maleimide $2 a$ in toluene: a) absorption - before (1) and after irradiation with light of $436 \mathrm{~nm}$ for 40 (2), 180 (3), 360 (4) and $720 \mathrm{~s}(5)\left(6.3 \cdot 10^{-5} \mathrm{~mol} \mathrm{~L}^{-1}\right)$; b) fluorescence of the same solutions $(1-5)$. 
The observed spectral changes are characteristic for the processes of photo-initiated rearrangement of hexatriene ring-opened forms $\mathbf{O}$ into cyclic 1,3-cyclohexadiene isomers $\mathbf{C}$ (Scheme 2 ) due to the establishment of the photostationary state. Its formation is caused by the substantial overlap of the absorption bands related to the $S_{0} \rightarrow S_{1}$ transition of the initial form $\mathbf{O}$ and the $S_{0} \rightarrow S_{2}$ transition of the photoinduced isomer $\mathbf{C}^{14,27}$ The cyclic isomers $\mathbf{2 a - c} \mathbf{C}$ did not fluoresce in contrast to the isomers $\mathbf{2 a - c} \mathbf{0}$.

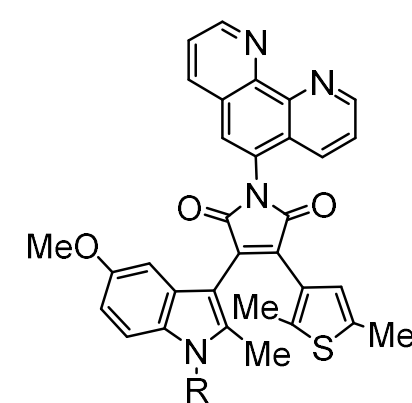

0

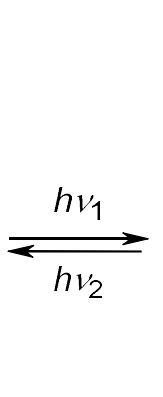

2a-c

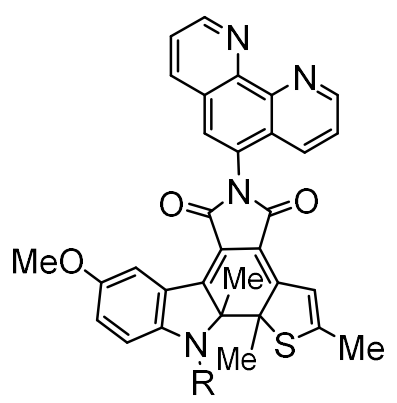

C

Scheme 2. Photoisomerization of maleimides 2a-c.

The ring-closed isomers $\mathbf{C}$ demonstrated high thermal stability, the intensities of their longest wavelength absorption bands were unaffected after $48 \mathrm{~h}$ at $293 \mathrm{~K}$. Irradiation of their violet-colored solutions in acetonitrile with visible light $\lambda_{\text {irr }}>500 \mathrm{~nm}$ led to complete restoration of the initial orange color due to the reopening into the initial forms 20.

Selective chromogenic activity of maleimides $2 \mathrm{a}-\mathrm{c}$ to cations of iron(II) was revealed upon addition of $d$ metal perchlorates $\left(\mathrm{Ni}^{2+}, \mathrm{Co}^{2+}, \mathrm{Cd}^{2+}, \mathrm{Cu}^{2+}, \mathrm{Pb}^{2+}, \mathrm{Zn}^{2+}, \mathrm{Fe}^{2+}\right.$ and $\left.\mathrm{Hg}^{2+}\right)$ to their solutions in acetonitrile. $\mathrm{Fe}^{2+}$ ions induce a significant increase in the intensity of the long-wave absorption bands simultaneously with bathochromic shift of $12 \mathrm{~nm}$ that causes a distinct "naked-eye" effect - visually distinguishable color change of the solutions from orange to red (Fig. 2). Among the other cations only $\mathrm{Co}^{2+}$ demonstrated a measurable effect (Fig. 3). According to the data of spectrophotometric titration and the isomolar series method, the most sensitive compound $\mathbf{2 a}$ forms with iron(II) cations a complex with 1:1 composition with a detection limit of 5.7 $\mu \mathrm{M}$.

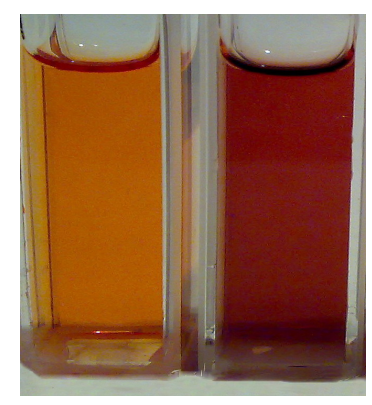

Figure 2. Visual color change in acetonitrile with $\mathbf{2 a}$ and $\mathrm{Fe}^{2+}$. 


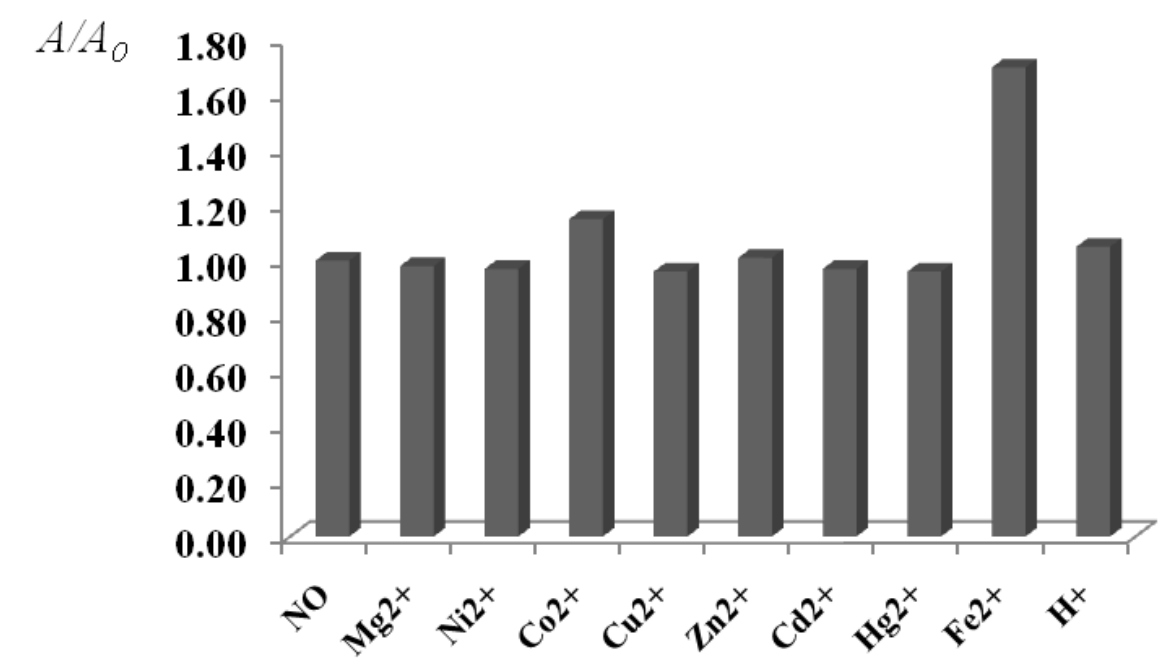

Figure 3. Changes in the absorption intensity of maleimide $2 a$ in acetonitrile at $480 \mathrm{~nm}$ after addition of the metal perchlorates $\left(c_{2 a} 5 \cdot 10^{-5} \mathrm{~mol} \mathrm{~L}^{-1}, c_{\text {cat. }} 5 \cdot 10^{-4} \mathrm{~mol} \mathrm{~L}^{-1}\right)$.

Complexes of ring-opened forms 2a-c O with $\mathrm{Fe}^{2+}$ in acetonitrile solutions are non-fluorescent, their irradiation with filtered light of the mercury lamp $436 \mathrm{~nm}$ did not lead to formation of the corresponding ringclosed forms $\mathbf{C}$, but did lead to thermally reversible dissociation (Scheme 3). ${ }^{29}$

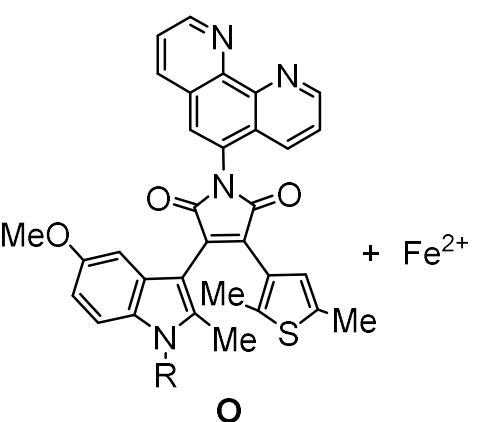

0

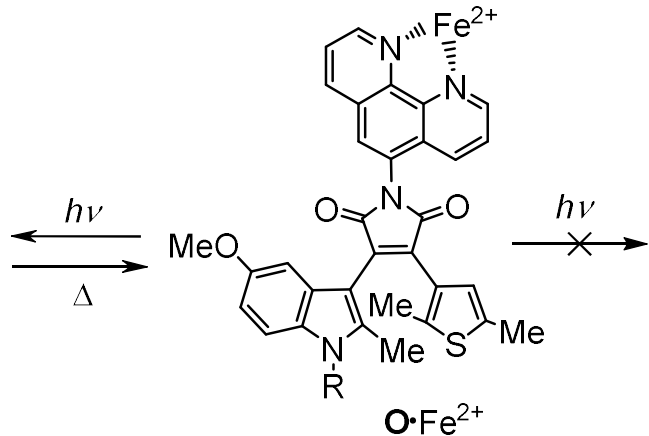

2a-c

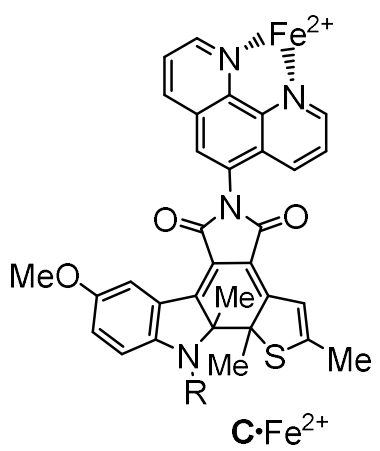

$\mathrm{C} \cdot \mathrm{Fe}^{2+}$

Scheme 3. Photoinitiated dissociation of maleimide complexes $\mathbf{2 a - c} \mathbf{0} \cdot \mathrm{Fe}^{2+}$ in acetonitrile.

\section{Conclusions}

New indolyl(thienyl)maleimides containing phenanthroline receptor in the bridge moiety were synthesized. The compounds exhibited photochromic and fluorescence properties in toluene solutions and "naked-eye" selective chemosensor activity to $\mathrm{Fe}^{2+}$ cations in acetonitrile solution.

\section{Experimental Section}

General. The IR spectra were recorded on a Varian Excalibur 3100 FT-IR instrument using the attenuated total internal reflection technique (ZnSe crystal). The ${ }^{1} \mathrm{H}$ NMR spectra in $\mathrm{CDCl}_{3}$ were recorded on a Varian Unity 300 
spectrometer $(300 \mathrm{MHz})$, the signals were referred with respect to the signals of residual protons of deuterosolvent $(7.24 \mathrm{ppm}), \delta$ values were measured with precision $0.01 \mathrm{ppm}$. Mass spectra were recorded on a Shimadzu GCMS-QP2010SE instrument with direct sample entry into the ion source (EI, $70 \mathrm{eV})$. Toluene and acetonitrile of the spectroscopic grade and $d$-metal perchlorates (Aldrich) were used to prepare solutions. Elemental analysis was performed on a KOVO CHN-analyzer. Melting points were determined on a PTP (M) instrument.

General procedure for the synthesis of pyrrole-2,5-diones 2a,b. 1,10-Phenanthrolin-5-amine ${ }^{30}(0.13 \mathrm{mmol}, 25$ $\mathrm{mg})$ and $\mathrm{NaOAc}(0.13 \mathrm{mmol}, 11 \mathrm{mg})$ in an argon atmosphere were added with stirring to a solution of 0.1 mmol of 3-(2,5-dimethylthien-3-yl)-4-(5-methoxy-1,2-dimethyl-1H-indol-3-yl)- (1a), 3-(2,5-dimethylthien-3-yl)4-(1-ethyl-5-methoxy-2-methyl-1H-indol-3-yl)- (1b) or 3-(1-benzyl-5-methoxy-2-methyl-1H-indol-3-yl)-4-(2,5dimethylthien-3-yl)furan-2,5-dione ${ }^{27,28,31}(\mathbf{1 c})$ in $\mathrm{AcOH}(2 \mathrm{~mL})$ and $n$ - $\mathrm{BuOH}(2 \mathrm{~mL})$. The reaction mixture was heated at reflux for $4 \mathrm{~h}$. The solvent was removed using a rotary evaporator. A crude residue was purified by column chromatography on silica gel $\left(\mathrm{CHCl}_{3}\right)$ and recrystallized $(n-\mathrm{BuOH})$.

3-(2,5-Dimethylthien-3-yl)-4-(5-methoxy-1,2-dimethyl-1H-indol-3-yl)-1-(1,10-phenanthrolin-5-yl)-1H-pyrrole2,5-dione (2a). Yield 35\%, red solid, mp 221-222 ${ }^{\circ} \mathrm{C}$. IR $\left(v_{\max }, \mathrm{cm}^{-1}\right)$ : 1701 (C=O), 1697 (C=C). ${ }^{1} \mathrm{H} \mathrm{NMR} \mathrm{(300} \mathrm{MHz,}$ $\left.\mathrm{CDCl}_{3}\right): \delta 1.82(\mathrm{~s}, 3 \mathrm{H}, \mathrm{Me}), 2.42(\mathrm{~s}, 3 \mathrm{H}, \mathrm{Me}), 2.44(\mathrm{~s}, 3 \mathrm{H}, \mathrm{Me}), 3.60(\mathrm{~s}, 3 \mathrm{H}, \mathrm{Me}), 3.72(\mathrm{~s}, 3 \mathrm{H}, \mathrm{Me}), 6.45(\mathrm{~s}, 1 \mathrm{H}$, thienyl $H), 6.79-6.83(\mathrm{~m}, 1 \mathrm{H}$, indole $H), 6.97(\mathrm{~s}, 1 \mathrm{H}$, indole $H), 7.16-7.19(\mathrm{~m}, 1 \mathrm{H}$, indole $H)$, 7.67-7.71 $(\mathrm{m}, 2 \mathrm{H}$, phenant. H), $7.91(\mathrm{~s}, 1 \mathrm{H}$, phenant. H), $8.18(\mathrm{~d}, J 9.0 \mathrm{~Hz}, 1 \mathrm{H}$, phenant. H), $8.29(\mathrm{~d}, J 9.0 \mathrm{~Hz}, 1 \mathrm{H}$, phenant. H), 9.26 (s, $2 \mathrm{H}$, phenant. H). MS (EI, $70 \mathrm{eV}), \mathrm{m} / \mathrm{z}: 559[\mathrm{M}+1]^{+}(23 \%), 558[\mathrm{M}]^{+}(40), 543(26), 482$ (12), 135 (100). Anal. Calcd. for $\mathrm{C}_{33} \mathrm{H}_{26} \mathrm{~N}_{4} \mathrm{O}_{3} \mathrm{~S}$ : C, 70.95; $\mathrm{H}, 4.69 ; \mathrm{N}, 10.03$. Found: $\mathrm{C}, 71.02 ; \mathrm{H}, 4.66 ; \mathrm{N}, 10.09 \%$.

3-(2,5-Dimethylthien-3-yl)-4-(1-ethyl-5-methoxy-2-methyl-1H-indol-3-yl)-1-(1,10-phenanthrolin-5-yl)-1Hpyrrole-2,5-dione (2b). Yield 47\%, red solid, mp 228-229 ${ }^{\circ} \mathrm{C}$. IR $\left(V_{\max }, \mathrm{cm}^{-1}\right): 1711$ (C=O), $1698(\mathrm{C}=\mathrm{C}) .{ }^{1} \mathrm{H} N M R$ $\left(300 \mathrm{MHz}, \mathrm{CDCl}_{3}\right): \delta 1.35(\mathrm{t}, J 6.0 \mathrm{~Hz}, 3 \mathrm{H}, \mathrm{Me}), 1.76(\mathrm{~s}, 3 \mathrm{H}, \mathrm{Me}), 2.38(\mathrm{~s}, 3 \mathrm{H}, \mathrm{Me}), 2.40(\mathrm{~s}, 3 \mathrm{H}, \mathrm{Me}), 3.58(\mathrm{~s}, 3 \mathrm{H}$, $\mathrm{Me}), 4.14\left(\mathrm{q}, J 3.0 \mathrm{~Hz}, 2 \mathrm{H}, \mathrm{CH}_{2}\right), 6.46(\mathrm{~s}, 1 \mathrm{H}$, thienyl $\mathrm{H}), 6.78-6.80(\mathrm{~m}, 1 \mathrm{H}$, indole $\mathrm{H}), 6.96(\mathrm{~s}, 1 \mathrm{H}$, indole H), 7.16$7.17(\mathrm{~m}, 1 \mathrm{H}$, indole $\mathrm{H}), \mathbf{7 . 6 4 - 7 . 6 7}(\mathrm{m}, 2 \mathrm{H}$, phenant. $\mathrm{H}), 789(\mathrm{~s}, 1 \mathrm{H}$, phenant. $\mathrm{H}), 8.15-8.20$ (m, $2 \mathrm{H}$, phenant. $H)$, 9.18-9.22 (m, 2H, phenant. H). MS (El, $70 \mathrm{eV}), \mathrm{m} / z$ : $573[\mathrm{M+1}]^{+}(42 \%), 572[\mathrm{M}]^{+}(28), 557$ (13), 147 (100). Anal. Calcd. for $\mathrm{C}_{34} \mathrm{H}_{28} \mathrm{~N}_{4} \mathrm{O}_{3} \mathrm{~S}: \mathrm{C}, 71.31 ; \mathrm{H}, 4.93 ; \mathrm{N}, 9.78$. Found: $\mathrm{C}, 71.25 ; \mathrm{H}, 4.90 ; \mathrm{N}, 9.73 \%$.

3-(1-Benzyl-5-methoxy-2-methyl-1H-indol-3-yl)-4-(2,5-dimethylthien-3-yl)-1-(1,10-phenanthrolin-5-yl)-1Hpyrrole-2,5-dione (2c). Yield 52\%, red solid, mp 201-202 ${ }^{\circ} \mathrm{C}$. IR $\left(v_{\max }, \mathrm{cm}^{-1}\right): 1707$ (C=O), $1701(\mathrm{C}=\mathrm{C}) .{ }^{1} \mathrm{H} N M R$ $\left(300 \mathrm{MHz}, \mathrm{CDCl}_{3}\right): \delta 1.85$ (s, 3H, Me), 2.37 (s, 3H, Me), $2.43(\mathrm{~s}, 3 \mathrm{H}, \mathrm{Me}), 3.60(\mathrm{~s}, 3 \mathrm{H}, \mathrm{Me}), 5.35\left(\mathrm{~s}, 2 \mathrm{H}, \mathrm{CH}_{2}\right), 6.51$ $(\mathrm{s}, 1 \mathrm{H}$, thienyl $\mathrm{H}), 6.75-6.79(\mathrm{~m}, 1 \mathrm{H}$, arom. $\mathrm{H}), 7.00-7.14(\mathrm{~m}, 4 \mathrm{H}$, arom. $\mathrm{H}), 7.28-7.32(\mathrm{~m}, 3 \mathrm{H}$, arom. $\mathrm{H}), 7.67-7.73$ (m, $2 \mathrm{H}$, phenant. $\mathrm{H}), 7.93(\mathrm{~s}, 1 \mathrm{H}$, phenant. $\mathrm{H}), 8.20(\mathrm{~d}, J 9.0 \mathrm{~Hz}, 1 \mathrm{H}$, phenant. $\mathrm{H}), 8.31(\mathrm{~d}, J 9.0 \mathrm{~Hz}, 1 \mathrm{H}$, phenant. H), 9.27 (s, 2H, phenant. H). MS (El, $70 \mathrm{eV}), \mathrm{m} / \mathrm{z}: 635[\mathrm{M}+1]^{+}(15 \%), 634[\mathrm{M}]^{+}(33), 619$ (9), 93 (100). Anal. Calcd. for $\mathrm{C}_{39} \mathrm{H}_{30} \mathrm{~N}_{4} \mathrm{O}_{3} \mathrm{~S}: \mathrm{C}, 73.80 ; \mathrm{H}, 4.76 ; \mathrm{N}, 8.83$. Found: $\mathrm{C}, 73.77 ; \mathrm{H}, 4.76 ; \mathrm{N}, 8.80 \%$.

\section{Acknowledgements}

The work was supported by State Assignment in the field of scientific activity of Russian Federation (Initiative research - project No. 4.6497.2017/8.9; Leading researchers on an ongoing basis - Bren V.A., assignment No. 4 .5593.2017/6.7). 


\section{References}

1. Crano, J. C.; Guglielmetti, R. J. Organic photochromic and thermochromic compounds; Plenum Press: New York, 1999.

2. Minkin, V. I. Russ. Chem. Bull. 2008, 57, 687.

http://dx.doi.org/10.1007/s11172-008-0111-y

3. Andreasson, J.; Pischel, U. Chem. Soc. Rev. 2015, 44, 1053.

http://dx.doi.org/10.1039/C4CS00342J

4. Zhang, J.; Zou, Q.; Tian, H. Adv. Mater. 2013, 25, 378.

http://dx.doi.org/10.1002/adma.201201521

5. Velema, W. A.; Szymanski, W.; Feringa, B. L. J. Am. Chem. Soc. 2014, 136, 2178. http://dx.doi.org/10.1021/ja413063e

6. Natali, M.; Giordani, S. Chem. Soc. Rev. 2012, 41, 4010.

http://dx.doi.org/10.1039/C2CS35015G

7. Wang, G.; Zhang, J. J. Photochem. Photobiol. C. 2012, 13, 299.

http://dx.doi.org/10.1016/j.photochemrev.2012.06.002

8. Klajn, R. Chem. Soc. Rev. 2014, 43, 148.

http://dx.doi.org/10.1039/C3CS60181A

9. Nikolaeva, O. G.; Tsukanov, A. V.; Shepelenko, E. N.; Lukyanov, B. S.; Metelitsa, A. V.; Kostyrina, O.Y.; Dubonosov, A. D.; Bren, V. A.; Minkin, V. I. Int. J. Photoenergy 2009, 2009, Article ID 238615. http://dx.doi.org/10.1155/2009/238615

10. Nikolaeva, O. G.; Gaeva, E. B.; Shepelenko, E. N.; Tsukanov, A. V.; Metelitsa, A. V.; Lukyanov, B. S.; Dubonosov, A. D.; Bren, V. A.; Minkin, V. I. Russ. J. Org. Chem. 2009, 45, 1091. http://dx.doi.org/10.1134/S1070428009070173

11. Rueck-Braun, K.; Mayer, K.; Hebert, A.; Michalik, F. in Organic Photochemistry and Photobiology; Griesbeck, A.; Oelgemöller, M.; Ghetti, F. Eds.; CRC Press: Boca Raton, London, New York, 2012; pp 607626.

12. Yokoyama, Y. Chem. Rev._2000, 100, 1717. http://dx.doi.org/10.1021/cr980070c

13. Zmeeva, S. Yu.; Rybalkin, V. P.; Popova, L. L.; Tkachev, V. V.; Revinskii, Yu. V.; Tikhomirova, K. S.; Starikov, A. G.; Dubonosov, A. D.; Bren, V. A.; Aldoshin, S. M.; Minkin, V. I. Tetrahedron 2016, 72, 5776. http://dx.doi.org/10.1016/i.tet.2016.08.002

14. Irie, M.; Fukaminato, T.; Matsuda, K.; Kobatake, S. Chem. Rev. 2014, 114, 12174. http://dx.doi.org/10.1021/cr500249p

15. Shepelenko, E. N.; Revinskii, Y. V.; Dubonosov, A. D.; Minkin, V. I.; Tikhomirova, K. S.; Karamov, O. G.; Bren, V. A. Mendeleev Commun. 2016, 26, 193.

http://dx.doi.org/10.1016/j.mencom.2016.04.004

16. Rybalkin, V. P.; Popova, L. L.; Dubonosov, A. D.; Shepelenko, E. N.; Revinskii, Yu. V.; Bren, V. A.; Minkin, V. I. Russ. J. Org. Chem. 2001, 37, 1318. http://dx.doi.org/10.1023/A:1013143924110

17. Minkin, V. I.; Bren, V. A.; Dubonosov, A. D.; Tsukanov, A. V. Acylotropic intramolecular rearrangements of keto enamines of benzo[b]annelated heterocycles. Chem. Heterocycl. Compd. 2012, 48, 107. http://dx.doi.org/10.1007/s10593-012-0974-6 
18. Dubonosov, A. D.; Bren, V. A.; Chernoivanov, V. A. Russ. Chem. Rev. 2002, 71, 917. https://doi.org/10.1070/RC2002v071n11ABEH000745

19. Chernoivanov, V. A.; Dubonosov, A. D.; Bren, V. A.; Minkin, V. I.; Suslov, A. N.; Borodkin, G. S. Mol. Cryst. Liq. Cryst. A. 1997, 297, 239.

http://dx.doi.org/10.1080/10587259708036128

20. Harvey, E. C.; Feringa, B. L.; Vos, J. G.; Browne, W. R.; Pryce, M. T. Coord. Chem. Rev. 2015, 77, 282. https://doi.org/10.1016/i.ccr.2014.06.008

21. Shepelenko, E. N.; Makarova, N. I.; Podshibyakin, V. A.; Tikhomirova, K. S.; Dubonosov, A. D.; Metelitsa, A. V.; Bren, V. A.; Minkin, V. I. Russ. J. Org. Chem. 2017, 53, 366. http://dx.doi.org/10.1134/S1070428017030095

22. Dubonosov, A. D.; Bren, V. A.; Minkin, V. I.; Shepelenko, E. N.; Tikhomirova, K. S.; Starikov, A. G.; Revinskii, Yu. V. Tetrahedron 2015, 71, 8817. http://dx.doi.org/10.1016/j.tet.2015.09.030

23. Alreja, P.; Kaur, N. RSC Adv. 2016, 6, 23169. http://dx.doi.org/10.1039/C6RA00150E

24. Wang, X.; Zheng, W.; Lin, H.; Liu, G.; Chen, Y.; Fang, J. Tetrahedron Lett. 2009, 50, 1536. https://doi.org/10.1016/j.tetlet.2008.12.109

25. Tolpygin, I. E.; Rybalkin, V. P.; Shepelenko, E. N.; Popova, L. L.; Revinskii, Yu. V.; Tsukanov, A. V.; Dmitrieva, O. I.; Dubonosov, A. D.; Bren, V. A.; Minkin, V. I. Rus. J. Org. Chem. 2008, 44, 557. http://dx.doi.org/10.1134/S1070428008040155

26. Wang, X.; Zheng, W.; Liu, G.; Lin, H. J. Lumin. 2010, 130, 52. https://doi.org/10.1016/j.jlumin.2009.07.018

27. Makarova, N. I.; Levchenko, P. V.; Shepelenko, E. N.; Metelitsa, A. V.; Kozyrev, V. S.; Rybalkin, V. P.; Bren, V. A.; Minkin, V. I. Russ. Chem. Bull. 2011, 60, 1899.

http://dx.doi.org/10.1007/s11172-011-0286-5

28. Shepelenko, E. N.; Makarova, N. I.; Karamov, O. G.; Dubonosov, A. D.; Podshibyakin, V. A.; Metelitsa, A. V.; Bren, V. A.; Minkin, V. I. Chem. Heterocycl. Compd. 2014, 50, 932. http://dx.doi.org/10.1007/s10593-014-1547-7

29. Bianchi, A.; Delgado-Pinar, E.; García-España, E.; Giorgi, C.; Pina, F. Coord. Chem. Rev. 2014, 260, 156. https://doi.org/10.1016/i.ccr.2013.09.023

30. García-Fresnadillo, D.; Orellana, G. Helv. Chim. Acta. 2001, 84, 2708. http://dx.doi.org/10.1002/1522-2675(20010919)84:9<2708::AID-HLCA2708>3.0.CO;2-M

31. Yoshida, T.; Arishima, K.; Ebisawa, F.; Hoshino, M.; Sukegawa, K.; Ishikawa, A.; Kobayashi, T.; Hanazawa, M.; Horikawa, Y. J. Photochem. Photobiol. A. 1996, 95, 265.

http://dx.doi.org/10.1016/1010-6030(95)04259-8 